\title{
Measuring the research impact of the book Folding and Fracturing of Rocks by John G. Ramsay
}

\author{
RICHARD J. LISLE ${ }^{1 *}$, FERNANDO BASTIDA² \& JESÚS ALLER ${ }^{2}$ \\ ${ }^{1}$ School of Earth and Ocean Sciences, Cardiff University, Cardiff CF10 3YE, UK \\ ${ }^{2}$ Departamento de Geología, Universidad de Oviedo, Spain \\ *Correspondence: Lisle@cf.ac.uk
}

\begin{abstract}
On the 50th anniversary of the publication of the book Folding and Fracturing of Rocks by John G. Ramsay we use an analysis of citations to assess the book's impact on research in the field of structural geology. Five topics dealt with in the book have had special success in terms of the number of citations: (1) superimposed folding; (2) fold classification based on layer thickness variation; (3) simple shear deformation; (4) the $R_{f} / \varphi$ method; and (5) the flexural-slip mechanism of folding. The great impact of this book can be seen in several examples where the book has inspired new lines of research, such as: progressive deformation, strain analysis, shear zones and folding analysis. Ramsay's great merit in writing his book was to have wisely known to apply the quantitative methodology of continuum mechanics to the analysis of the geological structures. We conclude that Folding and Fracturing of Rocks is the most influential textbook in the field of structural geology research.
\end{abstract}

This year marks the 50th anniversary of the publication of John Ramsay's textbook Folding and Fracturing of Rocks (Ramsay 1967), one of the bestknown English-language textbooks in the geological sciences.

The early chapters of the book cover the basic groundwork of stress and strain together with the relevant mathematics. This leads on to

a study of fracture and flow and the geological aspects of fracturing and folding of rock materials which, it is hoped, will supplement the textbooks of descriptive structural geology and lead to an understanding of the fundamentals of these processes (Ramsay 1967 Preface).

The result is a book with a unique approach that distinguishes it from its predecessors.

This paper examines various ways of assessing the success of a textbook and then attempts to apply these to assess objectively the impact of Ramsay (1967) on structural geology research in the last half-century.

\section{Assessing the success of textbooks}

There are several different types of textbooks: (1) those that are designed to accompany a taught course often at undergraduate level; (2) those that deal with specific fundamental topics relevant to research; and (3) reference texts that offer specific information required for research.

One possible index of the scientific success of a textbook is the number of copies sold. This may be applicable to textbooks of type (1) above but less so for type (3) where sales are principally restricted to large libraries. Type (2) textbook sales are limited by the audience, that is the number of scientists undertaking research in the specific field covered by the book in question. Ramsay (1967) belongs to the latter category and, therefore, solely the number of copies sold is unlikely to be an adequate indicator of its success.

Since researchers make up a major part of this book's readership, it seems logical that gauging success should involve measuring the impact of the book on the scientific output of those researchers. To do this we use the number of citations of the book, compiling the data from Google Scholar. Although Scholar is not comprehensive, for example it does not include some non-English language publications, a measure based on citation count permits a comparison to be made of Ramsay's book with other textbooks.

\section{Citation count of structural geology textbooks}

Table 1 lists the top ten most-cited English-language textbooks concerned with mainstream structural geology (Fig. 1a). Books devoted to specialist aspects of structural geology (e.g. the highly-cited book on microstructures by Passchier \& Trouw 1996, 2005) were not included in the survey.

Ramsay (1967) is the textbook with the greatest number of citations, with Modern Structural 


\section{R. J. LISLE ET AL.}

Table 1. Structural geology textbooks and their total citations up to April 2017

\begin{tabular}{lr}
\hline Billings (1942, 1954, 1972) & 1240 \\
Davis (1984), Davis \& Reynolds (1996), & 1006 \\
$\quad$ Davis et al. (2012) & \\
De Sitter (1956, 1964) & 997 \\
Hobbs et al. (1976) & 1296 \\
Price \& Cosgrove (1990) & 1071 \\
Ramsay (1967, 2004) & 4076 \\
Ramsay \& Huber Vol. 2 (1987) & 3435 \\
Suppe (1984) & 1058 \\
Turner \& Weiss (1963) & 1136 \\
Twiss \& Moores (1992, 2006) & 1260 \\
\hline
\end{tabular}

Geology Vol. 2 (Ramsay \& Huber 1987) coming close behind. These two books together have a lifetime sum of 7511 citations which correspond to $45 \%$ of the total citations for the top ten textbooks.

Impressive though these figures are, it is likely that the citation ranking based on the scores in Table 1 is influenced by an age effect, that is that older publications have had more time to accumulate more citations. To compensate for this age bias, we calculated average annual citations for the ten books in Table 1. These citation rates are shown as a histogram in Figure 1b. As a result of this adjustment the older books by De Sitter and Billings drop out of the top ten to be replaced in positions three and ten by more recent books by Fossen (2010) and Pollard \& Fletcher (2005) respectively. Modern Structural Geology Vol. 2 by Ramsay \& Huber (1987) has knocked Folding and Fracturing off the top spot. We will come back to this point later.

However, there is another bias; this time one that favours higher average annual citations for younger books. This is due to the overall increase in the number of scientific papers over the decades. To illustrate this effect, we counted the number of publications per year that including the search words 'geological structure' using Web of Science. The results (Fig. 2) indicate that since 1990 the number of such articles have roughly doubled every eight years. This would mean that an old book is likely to have relatively few citations from its early lean years, whereas a new book will have benefited from the abundance of citing papers throughout its lifetime. We have not attempted to correct for this factor, though the corrected average annual citation would produce an improved score for older textbooks. This effect may help explain why Ramsay \& Huber (1987) outperformed Ramsay (1967) in Figure 1b.

There is evidence that the yearly citation performances of Ramsay (1967) and Ramsay \& Huber (1987) are related (Fig. 3). Citations for the former started to decline significantly around 1987, when the latter appeared, and only started to increase again around 2000 (Fig. 3a). When these citation data are merged with those for Ramsay \& Huber (1987) shown in Figure 3b, the combined citation rate is remarkably constant (Fig. 3c). This suggests that these two textbooks, which have a significant overlap in the topics they cover, are actually feeding from the same citation pool. This combined 'book' has spectacular statistics: approximately 300 citations per year, and 7000 in total.

\section{To which topics do the citations refer?}

In the preceding section we have demonstrated that Ramsay's (1967) textbook has had an impressive citation history throughout its 50-year lifetime and that John Ramsay as an English-language author has outstripped all competitors in his field. In this section we attempt to discover the secret of the book's success by analysing more closely its citation statistics. The book's ten chapters deal with a range of topics covering the spectrum of structural geology. Table 2 lists the 69 topics identified. Which of these topics have produced the most citations?

To answer that we analysed a sample of 625 from the 4076 articles that have cited the book. The (a)

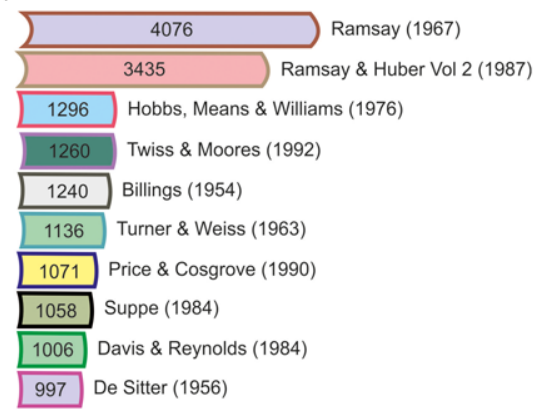

(b)

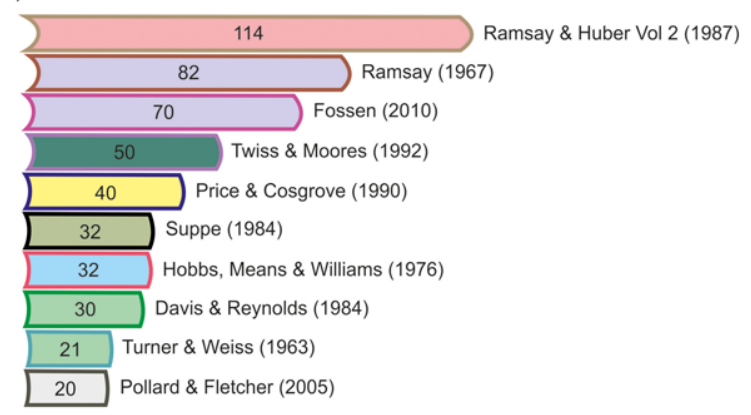

Fig. 1. Citations of structural geology textbooks: (a) total citations since publication; (b) average annual citations. 


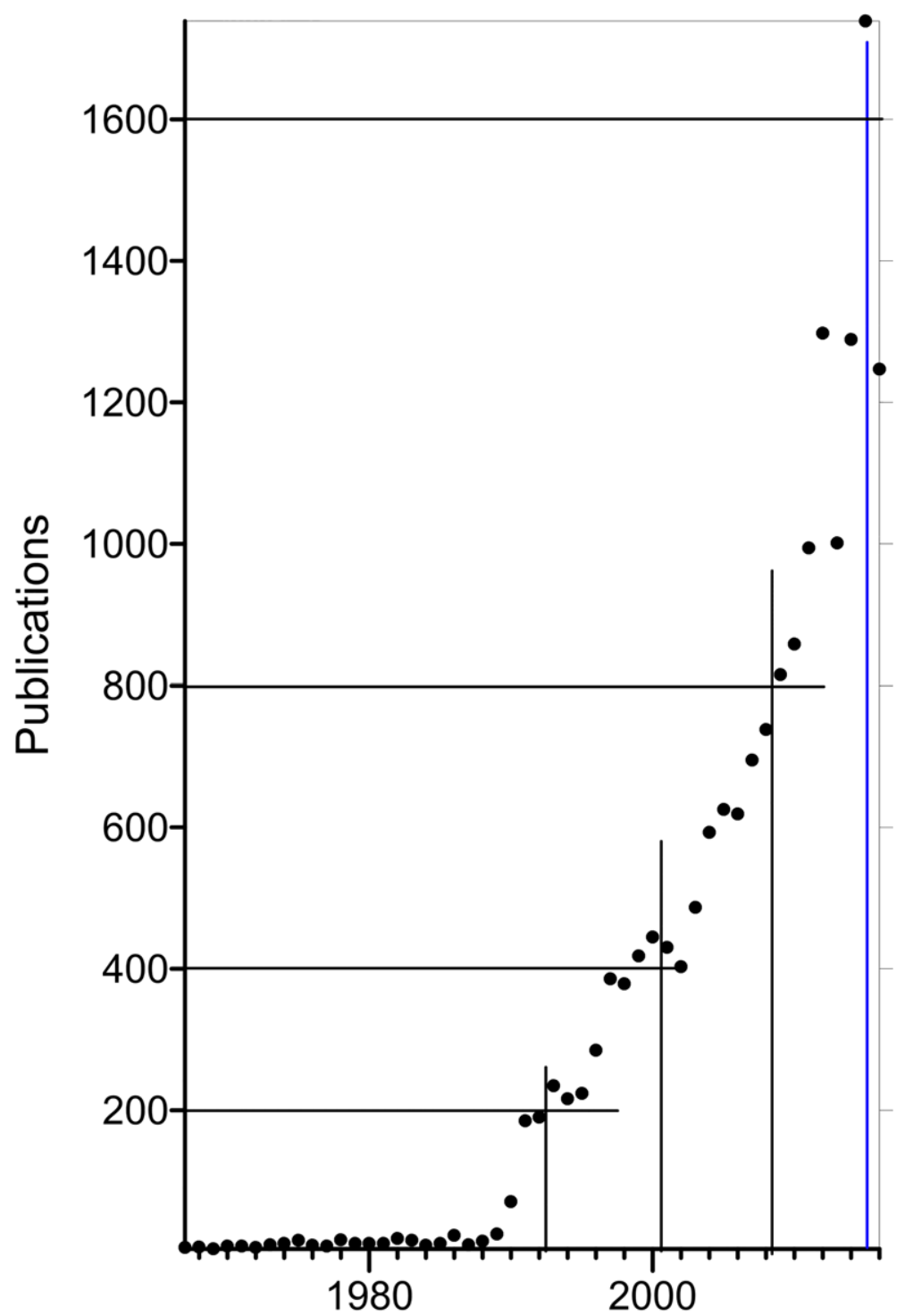

Fig. 2. Number of publications containing the keyword 'geological structure' (Source: Web of Science Index, accessed April 2017). The number of such publications per year has approximately doubled every eight years.

sampled articles are selected according to the number of citations they themselves had obtained to date and are therefore likely to be mainstream works in the field. For each article in the sample we recorded which topic, from the total of 69 topics identified (Table 2) within the book, was being cited. A number of citations for each topic is thus obtained (Tables $2 \& 3$ ) and this allows identification of those subjects dealt with in the book that have been most relevant to subsequent research.

There are five topics covered in Folding and Fracturing of Rocks that stand out in terms of the number of citations they have attracted (Fig. 4): superimposed folds, fold classification, simple shear, the $R_{f} / \varphi$ method of strain analysis and the flexuralslip mechanism of folding.

\section{Superimposed folding (Chapter 10)}

The 1950s and '60s saw major advances in the techniques for the recognition of structures resulting from multiple ductile deformations, e.g. Ramsay (1958, 1962b), Weiss (1959) and Carey (1962). One aspect of this work was to gain understanding 
(a)

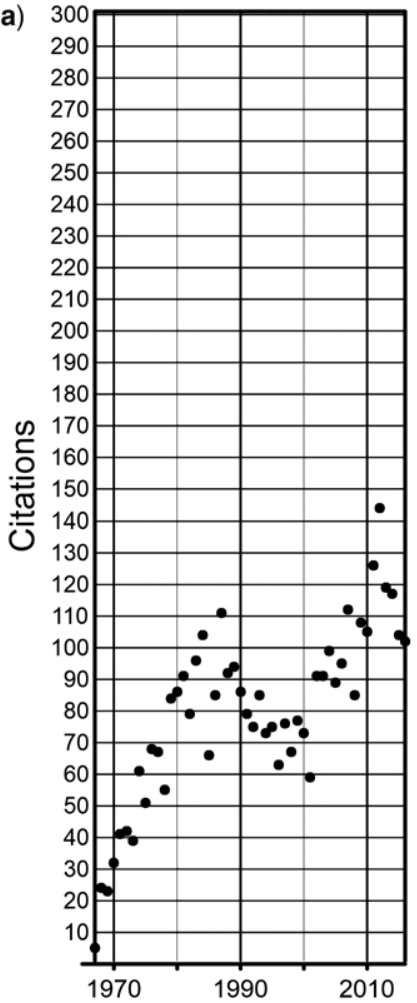

(b)

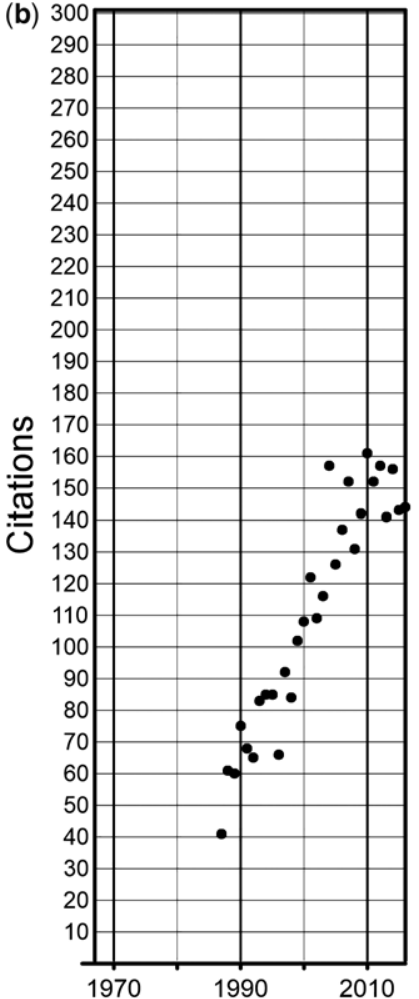

(c)

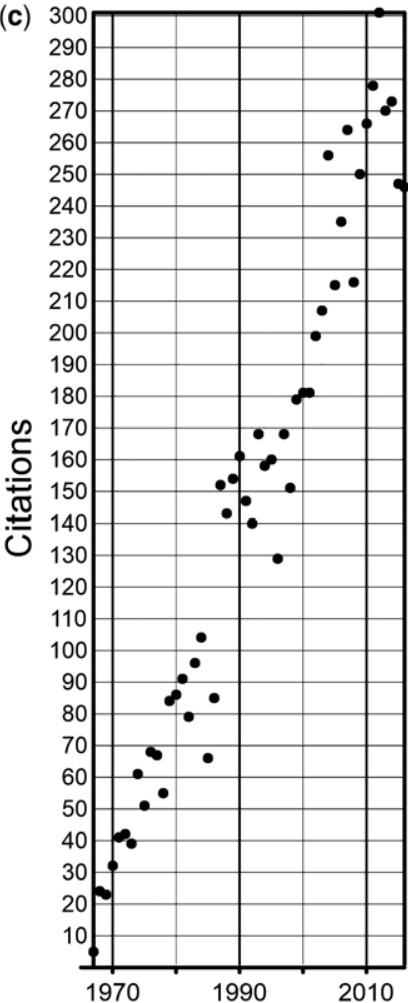

Fig. 3. Annual citations (a) Ramsay (1967), (b) Ramsay \& Huber (1987), (c) Combined data from (a) and (b).

Table 2. Chapter titles, topics covered in each chapter and the number of times cited in a sample of 625 highly-cited articles

Chapter 1: Stereograms(4) - Statistical methods(3) - Best great circle(0) - Best cone(1)

Chapter 2: Shear stress(2) - Normal stress(0) - Principal stresses(5) - Hydrostatic stress(1) - Deviatoric stress (0) - Stress trajectories(6) - Stress superimposition(1) - Photoelasticity(0)

Chapter 3: Strain compatibility(1) - Measurement of 2D strain(1) - Longitudinal / shear strain(9) -

Homogeneous/inhomogeneous strain(4) - Simple shear(49) - Tension gashes(11) - Changes of angles(3) -

Mohr circle(8) - Strain invariants $(0)$ - Pinch and swell $(0)$ - Ptygmatic folds $(0)$ - Lines of no finite elongation (1) - Strain ellipse(3)

Chapter 4: Change of line length(0) - Surface of no finite elongation(7) - Shear strain(2) - Finite strain ellipsoid(12) - Changes of angles(1) - Flinn diagram(7) - Ellipsoid from 2D data(4) - 3D Mohr circle for strain(1) - Populations of passive markers(3) - Strain superimposition(6) - Volume change(3) -Progressive deformation/ rotational strain(15) - Strain and foliations(23) - Cleavages(1) - Pressure shadows(1)

Chapter 5: Spherical markers(10) - Grain centre methods(3) - Ellipsoidal markers(9) - Rf/phi method(40) Preferred orientation/pebbles(0) - Competence contrasts(8) - Fossils(7) - Boudins(28) - Folded layers(2) Pressure solution(8)

Chapter 6: Stress/strain experiments $(0)$ - Rheological models(3) - Fracture theory $(7)$ - Stress functions and faults(2) - Stream functions(2)

Chapter 7: Description of folds(25) - Classification of folds/isogons(70) - Buckling mechanics(28) - Flexural slip / flow(33)- Tangential longitudinal strain(11) - Homogeneous flattening(2) - Cleavage patterns in folds (7) - Strain in incompetent layer(1) - Shear folding(5) - Kink bands(5) - Chevron folds(5)

Chapter 8: Folded lineations(3)

Chapter 9: Flooding of obliquely inclined surfaces(4)

Chapter 10: Superimposed folding(98) 
Downloaded from http://sp.lyellcollection.org/ by guest on January 4, 2019

RESEARCH IMPACT OF FOLDING AND FRACTURING OF ROCKS

Table 3. The five most-cited topics dealt with in Ramsay (1967)

\begin{tabular}{lcc}
\hline Topic & $\begin{array}{c}\text { No of citations } \\
\text { in sample }\end{array}$ & $\begin{array}{c}\text { Estimated } \\
\text { total citations }\end{array}$ \\
\hline Superimposed folding types & 98 & 627 \\
Fold classes based on layer thickness & 70 & 456 \\
Simple shear deformation & 49 & 319 \\
$R_{f} / \varphi$ method of strain analysis & 40 & 261 \\
Flexural-slip mechanism of folding & 33 & 215 \\
\hline
\end{tabular}

of the geometry, in 3D and in cross-section, of the fold shapes produced by the interference of two sets of folds of different ages. This allowed structural sense to be made of rock outcrops showing hitherto impossible complexity. Ramsay made a major contribution to this topic, in particular by devising a classification of 2D outcrop patterns and showing how these patterns relate to three types of $3 \mathrm{D}$ refolding geometries. This is one of many examples where the textbook deals with subjects that have been investigated by the author himself.

\section{Fold classification based on layer thickness variation (Chapter 7)}

Already by the end of the nineteenth century structural geologists were pointing out that folded layers show a range of cross-sectional geometries with respect to the way the layer thickness varies from limb to hinge. Van Hise (1894) recognized two classes of folds: parallel folds, with constant layer thickness measured perpendicular to the layering, and similar folds, with constant thickness, where the thickness is measured parallel to the fold's axial surface. Ramsay (1967), after a preliminary study (Ramsay $1962 a$ ), invented a classification scheme which could be applied to any fold based on graphs of layer thickness as a function of layer dip. The scheme has proved to be useful for deducing the relative rheology of a layer compared to its neighbours, for deducing folding mechanisms, and for predicting the shape of major folds that exceed the scale of the outcrop.

\section{Simple shear deformation (Chapter 2)}

This type of strain history is very important in the natural deformation of rocks. Prior to 1967, some geological textbooks mention simple shear but

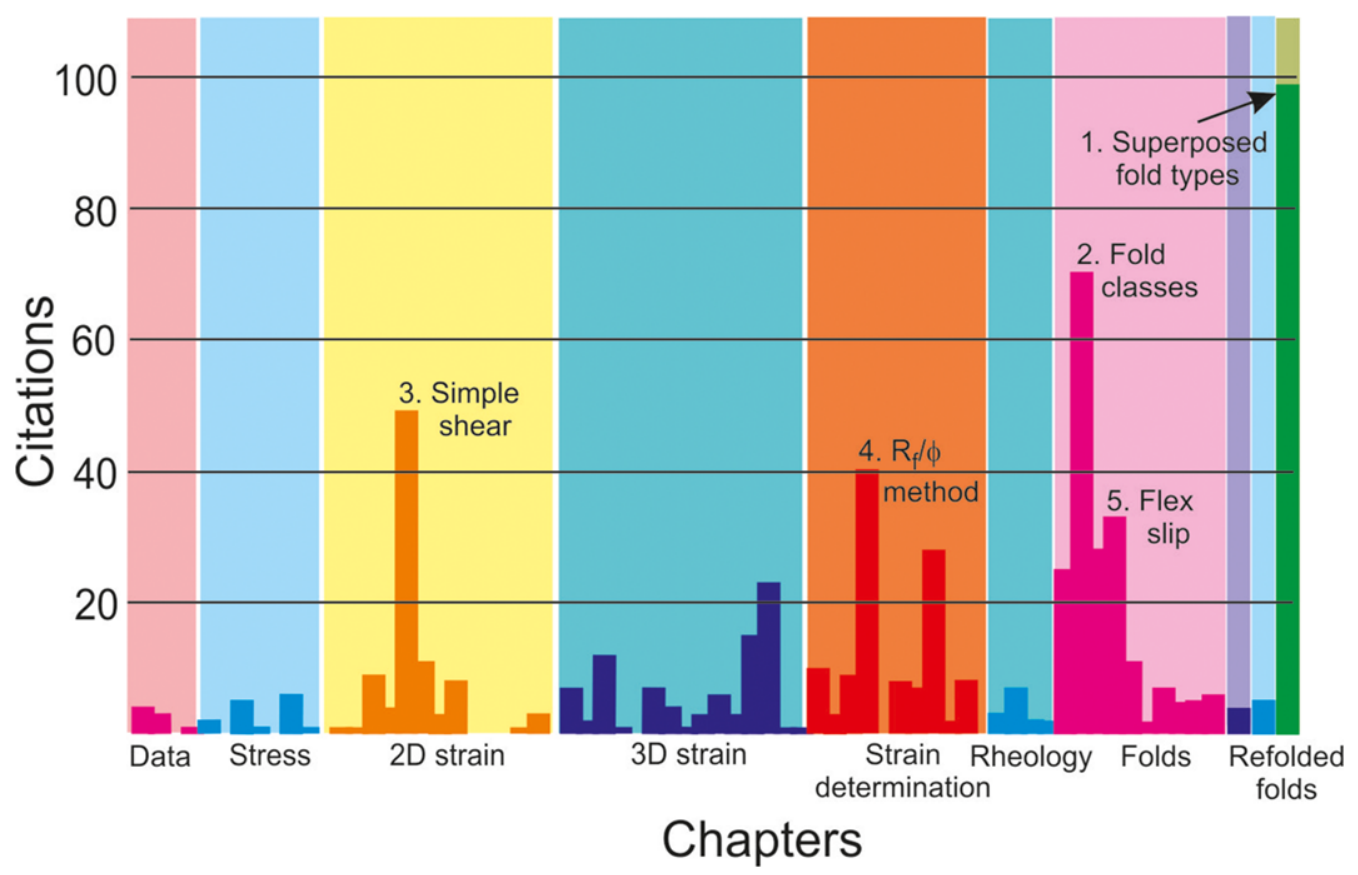

Fig. 4. The distribution of citations across the topics dealt with in the chapters of Ramsay (1967). 


\section{R. J. LISLE ET AL.}

without mathematical details, even though in the mechanics literature such details had been available for at least a century e.g. Thomson \& Tait (1867). For structural geologists, Ramsay (1967) has become the principal source of such information.

\section{The $\mathrm{R}_{\mathrm{f}} / \varphi$ method (Chapter 5)}

The book introduced numerical methods to the structural geologist. A good example of this is Chapter 5 where the subject of finite strain determination is explained and many new techniques are presented. An example of the latter is the $R_{f} / \varphi$ method, a method for finite strain estimation from elliptical markers. It has been widely applied to deformed clastic sedimentary rocks and has been cited in an estimated 260 subsequent publications (Table 2).

\section{The flexural-slip folding mechanism (Chapter 7)}

This mode of folding, in which layers retain their thickness and where inter-layer slippage accompanies tightening of the fold, was mentioned in textbooks going back at least to the early twentieth century (e.g. Leith 1913; Busk 1929). Flexural slip has often been invoked to model the deformation of well-bedded non-metamorphic sedimentary sequences. The treatment of this mechanism in Ramsay (1967) illustrates how the kinematic properties of this model can be predicted on the basis of a couple of geometrical assumptions. Kinematic modelling of this type has proved to be invaluable in structural geology, especially where there are insufficient data for the construction of mechanical models.

\section{Examples of research impact}

The citation statistics presented above demonstrate that Ramsay (1967) has firmly established itself as the major reference work in the field of structural geology. Beyond this, it is apparent that several concepts explained in this book have since been developed into major research themes in structural geology. Below we give examples of topics that were seeded by the book.

\section{Progressive deformation}

The term progressive deformation (Flinn 1962) conveys the idea that a rock's finite strain is the result of the superimposition of a series of deformation increments. Flinn (1962) considered the incremental rotation and straining of lines and planes during 3D co-axial deformation history. Ramsay (1967) describes and illustrates the structural consequences of such progressive deformation and also considers the more general case of non-coaxial strain histories.
This concept formed the foundation of many subsequent developments by others (e.g. Talbot 1970; Elliott 1972; Durney \& Ramsay 1973; Ramberg 1975; Ramsay \& Pfiffner 1982; Lister \& Williams 1983; Ghosh 1987; Passchier 1990; Wallis 1992; Simpson \& De Paor 1993; Tikoff \& Fossen 1995).

\section{Finite strain determination}

Chapter 5 of Ramsay (1967) described comprehensively the various available methods for finite strain analysis. These include earlier methods devised for specific deformed markers such as fossils (e.g. Breddin 1956) as well as methods utilizing particular graphical constructions, e.g. the use of the Mohr circle (Brace 1961). This chapter, which also included a large number of new methods devised by the author, seems to have inspired an explosion in strain analysis research in the 1970s and '80s. This included the invention of many new methodologies, like the ingenious grain-centre method of Fry (1979) and new practical applications of the results of such analyses. Examples of the latter include the reconstruction of the pre-deformation geometry of geological structures (e.g. Woodward et al. 1986), the estimation of rheological contrasts between different lithologies (e.g. Gay 1969; Lisle et al. 1983) and the estimation of volumetric strains associated with rock deformation (e.g. Ramsay \& Wood 1973; Wright \& Platt 1982). In addition, the results of strain measurements have been used as evidence in debates about the structural significance of slaty cleavage (Wood 1974; Williams 1976), crystallographic fabrics (Law et al. 1986) and magnetic fabrics (Borradaile 1988).

The strain-measuring techniques described in Ramsay (1967) have found practical application in several regional strain surveys. Such studies allow the finite strain pattern to be mapped across an area which in turn can be used to constrain the mechanism by which the regional structures developed. Examples include the development of the fold-thrust belt of Switzerland (Ramsay et al. 1983) and the mode of emplacement of Zimbabwe igneous intrusions (Ramsay \& Huber 1983; Ramsay 1989).

\section{Shear zones}

It is now well known that shear zones are broadly tabular zones of concentrated strain and that such zones account for a major part of lithospheric deformation (see review of Fossen \& Cavalcante 2017). As such, the subject of shear zones has attracted much attention in terms of field and theoretical studies. Figure 5 shows the number of publications per year related to these structures. It shows the rapid growth in publications reaching around 700 papers per year currently. A number of bursts in publication rate appear to correlate with the appearance of Ramsay 


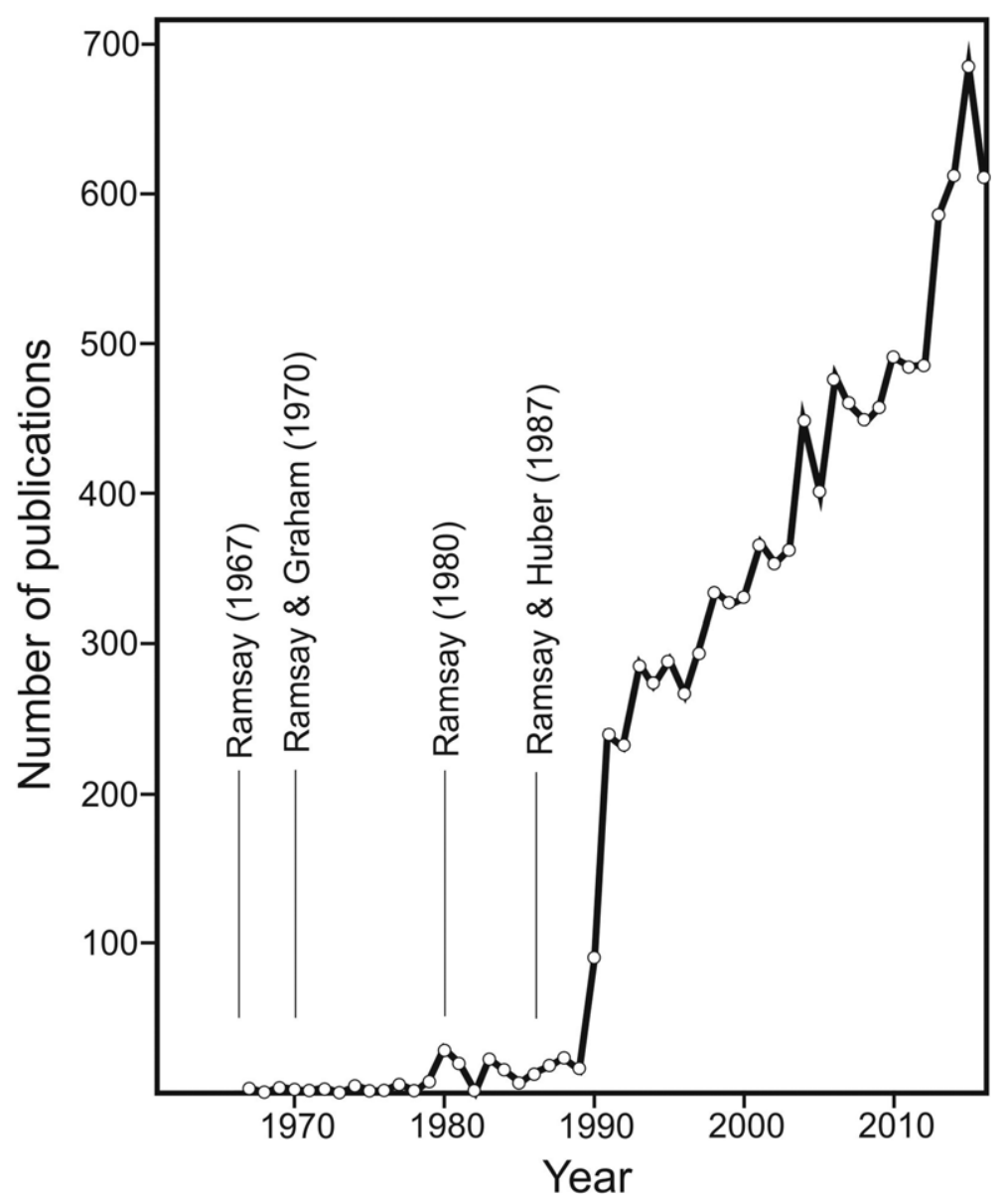

Fig. 5. Example of research impact: the increase in papers on shear zones in relation to the publication of papers of Ramsay and co-authors. Source: Web of Science Index.

\& Graham (1970), Ramsay (1980) and Ramsay \& Huber (1987); the first of these giving the original definition of the term 'shear zone'. However, Ramsay (1967, pp. 88-91) had three years earlier described parallel-sided zones containing cleavage and tension gashes which could be explained by localized progressive simple shear. Therefore, it seems reasonable to attribute the initiation of this research topic to Ramsay (1967).

\section{Folding analysis}

The impressive contribution of Ramsay (1967) to the quantitative knowledge of folding has been the basis for the development of numerous studies related to the geometry and kinematics of these structures. In this sense, we can highlight those dedicated to the classification of the folded layers (e.g. Hudleston 1973; Zagorčev 1993; Lisle 1997; Bastida et al. 2005; Adamuszek et al. 2011), those dedicated to the analysis of folding mechanisms and the strain distribution in folded layers (e.g. Hudleston 1973 , 1977; Tanner 1989; Lisle 1992, 1997; Hudleston \& Lan 1993; Fowler 1996; Ghosh 1996; Hudleston et al. 1996; Gutiérrez-Alonso \& Gross 1999; Bobillo-Ares et al. 2000, 2006; Bastida et al. 2003; Ormand \& Hudleston 2003; Shah \& Srivastava 2006; Srivastava \& Lisle 2004; Srivastava \& Shah 2006, 2008; Aller et al. 2008; Hudleston \& Treagus 2010), and those dedicated to the analysis of specific types of folds, for example chevron folds (e.g. Ramsay 1974; Narahara \& Wiltschko 1986; Fowler \& Winsor 1996; Bastida et al. 2007).

\section{Conclusion}

Unlike most structural geology textbooks, Ramsay's Folding and Fracturing of Rocks presents a content that is based on the results of the author's personal 


\section{R. J. LISLE ET AL}

research. It gives a new and complete vision of structural geology, introducing for the first time the basic concepts of continuum mechanics in a rigorous but accessible manner. One example of this is the description and detailed analysis of finite strain, and the establishment of numerous techniques to measure the strain suffered by rocks. These concepts and techniques are applied to the analysis of geological structures, in particular to the geometry and kinematics of folding. In several chapters, the author provides a novel quantitative view of the different patterns of strain distribution inside folded layers. The book also devotes attention to stress analysis, especially relevant to the study of fracturing of rocks.

As a whole, Ramsay's book provided a new quantitative approach to structural geology, placing special emphasis on the importance of meticulous analysis of deformed rocks and the minor structures that these display in order to understand the mechanisms involved in the geological evolution of a region. It can be said that this work marked a milestone in the development of knowledge in structural geology, being extremely useful for both students and researchers in this field. After 50 years since publication, it is clear that the influence of John Ramsay's book has deeply pervaded the field of structural geology.

Acknowledgements The authors are grateful to Mary Ford and Djordje Grujic for their helpful reviews.

Funding Financial support came from the Spanish Ministerio de Economía y Competitividad (project CGL2015-66997-R).

\section{References}

Adamuszek, M., Schmid, D.W. \& Dabrowski, D.W. 2011. Fold geometry toolbox: Automated determination of fold shape, shortening, and material properties. Journal of Structural Geology, 33, 1406-1416.

Aller, J., Bobillo-Ares, N.C., Bastida, F. \& Lisle, R.J. 2008. Total bulk strain in flattened parallel folds. Journal of Structural Geology, 30, 827-838.

Bastida, F., Bobillo-Ares, N.C., Aller, J. \& Toimil, N.C. 2003. Analysis of folding by superposition of strain patterns. Journal of Structural Geology, 25, 1121-1139.

Bastida, F., Aller, J., Bobillo-Ares, N.C. \& Toimil, N.C. 2005. Fold geometry: a basis for their kinematical analysis. Earth-Science Reviews, 70, 129-164.

Bastida, F., Aller, J., Toimil, N.C., Lisle, R.J. \& Bobillo-Ares, N.C. 2007. Some considerations on the kinematics of chevron folds. Journal of Structural Geology, 29, 1185-1200.
Billings, M.P. 1972. Structural Geology. 3rd edn. Prentice-Hall, Englewood Cliffs [1st edn 1942, 2nd edn 1954].

Bobillo-Ares, N.C., BastidA, F. \& Aller, J. 2000. On tangential longitudinal strain folding. Journal of Structural Geology, 21, 729-742.

Bobillo-Ares, N.C., Aller, J., Bastida, F., Lisle, R.J. \& ToIMIL, N.C. 2006. The problem of area change in tangential longitudinal strain folding. Journal of Structural Geology, 28, 1835-1848.

Borradaile, G.J. 1988. Magnetic susceptibility, petrofabrics and strain. Tectonophysics, 156, 1-20.

BRACE, W.F. 1961. Mohr construction in the analysis of large geological strain. Geological Society of America Bulletin, 72, 1059-1080.

BrEDDIN, H. 1956. Die tektonische Deformation der Fossilien im Rheinischen Schiefergebirge. Zeitschrift Deutsche Geologische Gesellschaft, 106, 227-305.

Busk, H.G. 1929. Earth Flexures. Cambridge University Press, Cambridge.

CAREY, W.S. 1962. Folding. Journal of Alberta Society of Petroleum Geology, 10, 95-144.

Davis, G.H., Reynolds, S.J. \& Kluth, C.F. 2012. Structural Geology of Rocks and Regions. 3rd edn. John Wiley, Chichester [1st edn 1984, 2nd edn 1996].

De Sitter, L.U. 1964. Structural Geology. 2nd edn. McGraw-Hill, New York [1st ed 1956].

DuRnEY, D.W. \& RAMSAY, J.G. 1973. Incremental strains measured by syntectonic crystal growths. In: DE JoNG, K.A. \& Scholten, R. (eds) Gravity and Tectonics. Wiley, New York, 67-96.

ElliotT, D. 1972. Deformation paths in structural geology. Geological Society of America Bulletin, 83, 2621-2638.

FlinN, D. 1962. On folding during three-dimensional progressive deformation. Quarterly Journal of the Geological Society, 118, 385-428.

Fossen, H. 2010. Structural Geology. Cambridge University Press, Cambridge.

Fossen, H. \& Cavalcante, G.C.G. 2017. Shear zones - a review. Earth Science Reviews, 171, 434-455.

FowLER, T.J. 1996. Flexural-slip generated bedding-parallel veins from central Victoria, Australia. Journal of Structural Geology, 18, 1399-1415.

Fowler, T.J. \& Winsor, C.N. 1996. Evolution of chevron folds by profile shape changes: Comparison between multilayer deformation experiments and folds of the Bendigo-Castlemaine goldfields, Australia. Tectonophysics, 258, 125-150.

FRY, N. 1979. Random point distributions and strain measurement in rocks. Tectonophysics, 60, 89-105.

GAY, N.C. 1969. The analysis of strain in the Baberton Mountain Land, Eastern Transvaal, using deformed pebbles. Journal of Geology, 77, 377-396.

Grosh, S.K. 1987. Measure of non-coaxiality. Journal of Structural Geology, 9, 111-113.

GHosH, S.K. 1996. Refolding by flexural flow. Journal of Structural Geology, 18, 1079-1087.

GutiérRez-Alonso, G. \& Gross, M.R. 1999. Structures and mechanisms associated with development of a fold in the Cantabrian Zone thrust belt, N W Spain. Journal of Structural Geology, 21, 653-670.

Hobbs, B.E., Means, W.D. \& Williams, P.F. 1976. An Outline of Structural Geology. John Wiley, Chichester. 


\section{RESEARCH IMPACT OF FOLDING AND FRACTURING OF ROCKS}

HudLESTON, P.J. 1973. Fold morphology and some geometrical implications of theories of fold development. $\mathrm{Tec}$ tonophysics, 16, 1-46.

HudLeston, P.J. 1977. Similar folds, recumbent folds, and gravity tectonics in ice and rocks. Journal of Geology, $\mathbf{8 5}, 113-122$.

Hudleston, P.J. \& LAN, L. 1993. Information from fold shapes. Journal of Structural Geology, 15, 253-264.

Hudleston, P.J. \& Treagus, S.H. 2010. Information from folds: a review. Journal of Structural Geology, 32, 2042-2071.

Hudleston, P.J., Treagus, S.H. \& Lan, L. 1996. Flexural flow folding: Does it occur in nature? Geology, 24, 203-206.

LAW, R.D., CASEy, M. \& KNIPE, R.J. 1986. Kinematic and tectonic significance of microstructures and crystallographic fabrics within quartz mylonites from the Assynt and Eriboll regions of the Moine Thrust zone, NW Scotland. Transactions of the Royal Society Edinburgh, 77, 99-125.

LeITH, C.K. 1913. Structural Geology. Henry Holt and Company, New York.

LisLE, R.J. 1992. Strain estimation from flattened buckle folds. Journal of Structural Geology, 14, 369-371.

LisLe, R.J. 1997. A fold classification scheme based on a polar plot of inverse layer thickness. In: SENGUPTA, S. (ed.) Evolution of Geological Structures in Micro to Macro-Scales. Chapman \& Hall, London, 323-339.

Lisle, R.J., Rondeel, H.E., Doorn, D., BRugGe, J. \& VAN DE GAAG, P. 1983. Estimation of viscosity contrasts and finite strain from deformed elliptical inclusions. Journal of Structural Geology, 5, 602-609.

Lister, G.S. \& Williams, P.F. 1983. The partitioning of deformation in flowing rock masses. Tectonophysics, 92, 1-33.

NarahaRa, D.K. \& WiltschKo, D.V. 1986. Deformation in the hinge region of a chevron fold, Valley and Ridge Province, central Pennsylvania. Journal of Structural Geology, 8, 157-168.

Ormand, C.J. \& Hudleston, P.J. 2003. Strain paths of three small folds from the Appalachian Valley and Ridge, Maryland. Journal of Structural Geology, 25, 1841-1854.

PAsschier, C.W. \& Trouw, R.A.J. 1996. Microtectonics. Springer Verlag, Berlin [2nd edn 2005].

PAsschIER, C.W. 1990. Reconstruction of deformation and flow parameters from deformed vein sets. Tectonophysics, 180, 185-199.

Pollard, D.D. \& Fletcher, R.C. 2005. Fundamentals of Structural Geology. Cambridge University Press, Cambridge.

Price, N.J. \& Cosgrove, J.W. 1990. Analysis of Geological Structures. Cambridge University Press, Cambridge.

RAMBerg, H. 1975. Particle paths, displacement and progressive strain applicable to rocks. Tectonophysics, 28, 1-37.

RAmsAy, J.G. 1958. Superimposed folding at Loch Monar, Inverness-shire and Ross-shire. Quarterly Journal of the Geological Society, 113, 271-307.

RAMSAY, J.G. $1962 a$. The geometry and mechanics of formation of 'similar' type folds. Journal of Geology, 70, 309-327.
RAMSAY, J.G. $1962 b$. Interference patterns produced by the superimposition of folds of 'similar' type. Journal of Geology, 70, 466-481.

Ramsay, J.G. 1967. Folding and Fracturing of Rocks. McGraw-Hill, New York [reprinted 2004 Blackburn Press, Spanish edition 1977].

Ramsay, J.G. 1974. The development of chevron folds. Geological Society of America Bulletin, 85, 1741-1754.

RAMSAY, J.G. 1980. Shear zone geometry: a review. Journal of Structural Geology, 2, 83-89.

RAMSAY, J.G. 1989. Emplacement kinematics of a granite diapir: the Chindamora batholith, Zimbabwe. Journal of Structural Geology, 11, 191-210.

RAMSAY, J.G. \& GRAHAM, R.H. 1970. Strain variation in shear belts. Canadian Journal of Earth Sciences, 7 , 786-813.

RAMSAY, J.G. \& Huber, M.I. 1983. The Techniques of Modern Structural Geology. Vol. 1, Strain Analysis. Academic Press.

RAMSAY, J.G. \& Huber, M.I. 1987. The Techniques of Modern Structural Geology. Vol. 2, Folds and Fractures. Academic Press, Cambridge, MA

Ramsay, J.G. \& Pfiffner, A. 1982. Arguments from finite strain states of naturally deformed rocks. Journal of Geophysical Research, 87, 311-321.

RAMSAY, J.G. \& WoOD, D.S. 1973. The geometric effects of volume change during deformation processes. Tectonophysics, 16, 236-277.

Ramsay, J.G., Casey, M. \& Kligfield, R. 1983. Role of shear in development of the Helvetic fold-thrust belt of Switzerland. Geology, 1, 439-442.

Shah, J. \& SRIVAstava, D.C. 2006. Strain estimation from flattened parallel folds: application of the Wellman method and Mohr circle. Geological Magazine, 143, 243-247.

Simpson, C. \& De Paor, D.G. 1993. Strain and kinematic analysis in general shear zones. Journal of Structural Geology, 15, 1-20.

SRIVASTAVA, D.C. \& LisLE, R.J. 2004. Rapid analysis of fold shape using Bezier curves. Journal of Structural Geology, 26, 1553-1559.

Srivastava, D.C. \& Sнah, J. 2006. A rapid method for strain estimation from flattened parallel folds. Journal of Structural Geology, 28, 1-8.

Srivastava, D.C. \& Shah, J. 2008. The 'isogon rosette' method for rapid estimation of strain in flattened folds. Journal of Structural Geology, 30, 444-450.

SupPe, J. 1984. Principles of Structural Geology. PrenticeHall, Englewood Cliffs.

Tацвот, C.J. 1970. The minimum strain ellipsoid using deformed quartz veins. Tectonophysics, 9, 47-76.

TANNER, P.W.G. 1989. The flexural-slip mechanism. Journal of Structural Geology, 11, 635-655.

Thomson, W. \& TAit, P.G. 1867. Treatise on Natural Philosophy. Vol. 1, Oxford University Press, Oxford.

Tikoff, B. \& Fossen, H. 1995. The limitations of threedimensional kinematic vorticity analysis. Journal of Structural Geology, 17, 1771-1784.

Turner, F.J. \& Weiss, L.E. 1963. Structural Analysis of Metamorphic Tectonites. McGraw-Hill, New York.

Twiss, R.J. \& Moores, E.M. 2006. Structural Geology 2nd edn. W.H. Freeman, New York [1st edn 1992]. 


\section{R. J. LISLE ET AL}

VAN Hise, C.R. 1894. Principles of North American PreCambrian Geology. US Geological Survey, 16th annual report, 581-843.

WALLIS, S.R. 1992. Vorticity analysis in a metachert from the Sanbagawa belt, SW Japan. Journal of Structural Geology, 14, 271-280.

WEISS, L.E. 1959. Geometry of superposed folding. Geological Society of America Bulletin, 70, 91-106.

WiLliams, P.F. 1976. Relationships between axial plane foliations and strain. Tectonophysics, 30, 181-196.
Wood, D.S. 1974. Current views of the development of slaty cleavage. Annual Review of Earth and Planetary Sciences, 2, 369-401.

Woodward, N.B., Gray, D.R. \& SPEAR, D.B. 1986. Including strain data in balanced cross-sections. Journal of Structural Geology, 8, 313-324.

Wright, T.O. \& PlatT, L.B. 1982. Pressure solution and cleavage in the Martinsburg Shale. American Journal of Science, 282, 122-135.

ZAGORČEV, I. 1993. The geometrical classification of folds and distribution of fold types in natural rocks. Journal of Structural Geology, 15, 243-251. 